\title{
THE CHALLENGES OF HINDU BALINESE'S MODIFICATION TO THE PRACTICE OF ZIKR RITUAL
}

\author{
Mauliya Risalaturrohmah \\ Indonesian Consortium for Religious Studies (ICRS), Graduate School, \\ Universitas Gadjah Mada (UGM) \\ $<$ Mauliya.Malik93@gmail.com>
}

\begin{abstract}
The issue of religious spiritual groups (Islam) in Indonesia rarely encounters the relation with non-Muslim contexts in the way how they perform religious ritual. Conversely, the Wahidiyah Foundation as Islamic organization representing Sufism, opens to non-Muslim without any requirement for conversion when practicing zikr ritual toward the formula of shalawat wahidiyah. This research examines the cases of Hindu Balinese performing zikr without violating their Hindu's identity. It links to the question on how Hindu Balinese modify zikr toward shalawat wahidiyah performance in the way they adapt it according to their own belief and why the emergence of tension occurs between a minority group of Hindu Balinese and internal community of Muslims within the Wahidiyah Foundation in local level of Bali during the practice of zikr ritual. By using ethnographical approach, process of collecting data is conducted in six regencies of Bali. This article uses Bell's ritual perspectives as the basic assumptions and tendencies in thinking about ritual activities in broader context. This research tries to counter the prejudice of religious conversion through the interpretation of other religious teachings in ritual activity representing a universalistic idea in Indonesia context.
\end{abstract}

Key words: Hindu Balinese, Sufism, Zikr, Shalawat Wahidiyah, Ritual

\section{Introduction}

This research will look at the case of Hindu members under an Islamic organization, the Wahidiyah Foundation, ${ }^{1}$ which focuses on six

1 Although the Wahidiyah Foundation (WF) is placed in Kediri, the structural management of its officials is regencies in Bali. This organization is centred in Kedunglo, Kediri, East Java. Established and founded by the figure of K.H. Abdoel Madjid Ma'roef (called as Kyai Madjid), the Wahidiyah

controlled by the WF in Center and spread to province, regency or city, sub-district, and village level. 
Foundation is known as the location of Islamic Boarding School of Kedunglo Al-Munadhoroh and actively performs shalawat wahidiyah ${ }^{2}$ as zikr practice. Representing Sufism as an additional reference beside Qur' an and hadist, the practice of shalawat wahidiyah in the Wahidiyah Foundation are followed by diverse religions since Kyai Madjid does not limit the follower and practitioner of its shalawat. It means that anyone of any religion could recite shalawat wahidiyah without the requirement of having religious conversion. Because of the flexibility to the practice of shalawat wahidiyah, there have a lot of people interested in accepting and reciting its shalawat including Muslim and nonMuslim followers. For example; there have a group of Christianity in Flores, Catholic practitioner in Kalimantan, and Hindu community in Bali. Significantly, people have to fully focus on their ethics and attitudes when reciting shalawat wahidiyah under the agenda of $z i k r$ ritual in order to purify the self (it refers to the heart, soul, and mind), because the goal of practicing shalawat wahidiyah is to return into God (fafirru ilalloh) in sincerity.

In Indonesia context, I argue that $z i k r$ is often linked to the Muslim activity as part of people's obedience to remember God and honour the Prophet. According to An-Naisaburi

2 Shalawat wahidiyah is an Arabic formula of collected shalawat which was written and created by K.H. Abdoel Madjid Ma'roef in 1963 and finished in 1981
(2007: p. 318), zikr means a part of (Islamic) pillar to approach God by performing spoken zikr (zikr lisan) and zikr by heart (zikr di dalam hati). To support the activity of $z i k r$ itself, the Wahidiyah Foundation hold the agenda of mujahadah and "doa bersama" by reciting shalawat wahidiyah in accordance with the guidance of Wahidiyah leader in Kediri, where it has been led by K.H. Abdul KH. Abdoel Latif Madjid . Thus, to some extent, its shalawat is easily accepted by all people from diverse religions.

In this research, I concerns with a group of Hindu Balinese who appeal on performing shalawat wahidiyah without violating their religious identity by adapting the shalawat wahidiyah in line with their belief. Meanwhile, in the broader context of Indonesia, this issue leads us to see the relation between a sensitive issue of building religious boundaries and the practice of universalistic view of ritual among people from different religions. I then argue that this research could bring us to a significant aspect of protecting religious identity in Indonesia context because the presence of religion is strongly used as such a wall to limit people's involvement to the practice of other religious activity. Thus, to some extent, there has always the rule obeyed by the practitioner of ritual behind their status as believers whom affiliate with one legalized religion in the context of Indonesia. In Balinese society, Hindu's 
identity could not even be separated from adat because the recognition of Hinduism as religion (agama) is strongly influenced by the politic of religion in Indonesia (Picard, 2011: p. 123). Following that issue, I want to assert that the idea of socio-religious politics of divinity in Balinese society is influenced by the religious policy of Indonesia. It means that in Indonesia the reinterpretation process of the recognition of religion (agama) have to appropriate with the national majority religion of Islam, such as, 'the principle of monotheism, scripturalism, and universal doctrine' (Hornbacher, 2011: p. 181). In this sense, the Indonesian Council of Hinduism (PHDI) promotes the Balinese culture to re-organize religious authority in accordance with the essential part of local Balinese tradition (Ibid: p.184).

“.....people living within a given territory and with specific (inherited) traditions/ customs (adat istiadat) that are considered typical for that place (UU No. 32, 2004: 5, I, $12) . .$. the way of this law is interpreted and implemented in Bali shows that the local understanding of adat definitely includes religion as well" (Hauser-Schaublin, 2011: p. 198).

Otherwise, I use an approach of Sufistic anthropology by Abdul Kadir Riyadi in order to look at how this study plays into the relation with the perspective of Sufism dialoging with culture and modernity, particularly in non-Muslim context. Therefore, it will be recontextualized by additional reference from Bell's view on how ritual is performed by the reality of believers in Indonesia context.

This research uses a qualitative method by using an ethnographical approach. Based on Creswell (2007), there are two popular forms of ethnography, namely the realist ethnography and the critical ethnography. Here I will use the realist ethnography to observe the case of Hindu Balinese. This approach will reflect 'a particular stance' which is taken by the researcher through the participants who are interviewed. An ethnography focuses on an entire cultural group which can be small or large groups where they involve and interact with many people over time, such as community social group (Creswell, 2007: p. 68). The data of this research is taken from the resources of library and observation in Bali. In accordance with the collecting of the data, I stay in Bali for two months. I am not only as an observer, but also a participant involving in all activities of zikr ritual under the agenda of mujahadah and "doa bersama" with Hindu and Muslim followers of Wahidiyah daily, weekly, and monthly including the event at the day of 'Safari Bulan Purnama' in some temples in order to examine what the people say, how people describe what they are doing and how they think about they're doing throughout the practice of $z i k r$ in Wahidiyah. 


\section{Dialoging Sufism with non-Muslim Context}

"Nobody knows everything about anything", said Swidler (2014: p.

15). This statement is the first point he conveyed to argue that dialogue is important. In the context of dialoguing Islam Sufi, it is significant to build a character of tolerance by accepting a tradition of socio-cultural condition toward Islam Sufi by the use of compromise approach (Simuh, 2016: p.16). In other words, the term of Islam Sufi represents Islam, it goes along with the debates against the emergence of some organizational innovation and creative formatting of Sufi practice in Indonesia that are considered as outside of Sufi order. For those who open access the tradition of indigenous groups (golongan kebatinan) teaching of the mystical practice (refers to Sufi) and facilitate the immanent experiences of God in order to increase the Christian or Muslim faith to the transcendent of God were positioned in suspiciousness by the government in the 1960s (Howell, 2012: p.67). This statement indicates that the groups of spiritual practice and mystical devotion do not easily get a privilege from government although some of the followers have been affiliated with one of six legalized religions.

In another case, when orthodox Sufi (refers to tarekat mu 'tabarah) struggled against the modernist Muslim whom discredited irrational ecstasy and brought the claim of spirit of religious spiritual teacher within Sufi order, it also creates a tension among society and government do nothing for it (Ibid, p.67). This is a significant problematic reason of mystical practices related to Sufi order and Sufi practice that are percieved as the separation of Islamic tradition. At the same time, this case also causes a feeling of distrustful in which people are willing to be conversed toward spiritual practices. Nevertheless, the historian Mark Sedgwick in Howell (2012: p. 3) has extended, "the term to apply to twentieth century self-described 'Sufi' groups formed in the West and open to non-Muslims without any requirement for conversion". It may be proven by the history of Sufi masters in Indonesia.

Wali Songo is one of the cases related to the involvement of Sufi masters rebuilding the King of HinduKejawen (Javanese Hindu) and it had emerged a conviction among people to honour the saint of Sufi figures (Simuh, 2016: p.22). In other words, I view that the development of Javanese literatures is also proliferated through the puppet tradition. The possibility is that the groups of people have started showing 'warisan budaya' (cultural inheritance) in order to maintain some certain practices of their own belief, such as the ethnic of Bali represented by Hinduism and the ethnic of Chinese represented by Buddha and Confucius (Howell, 2012: p.68).

Otherwise, the need of adapting 
the local tradition and social changes toward compromise approach by Simuh is important in order to avoid the specific tension among diverse society. If some Sufi and religious leaders of Sufi order are able to lead Sufism cooperatively, there have been strong possibilities where people who strongly maintain their local tradition can accept the Sufi tradition without emerging the tension (Simuh. 2016: p. 25). To some extent, I argue that Sufism in Indonesia will be more acceptable if it is kept away from doctrines which separates the aspect of monotheistic religion, Universalist of state (NKRI, Pancasila, and UUD), and the cultural values.

The emergence of religious groups in line with Sufism is another factor why nowadays the Sufi practice is followed by many people from different background. One of modernist 'ulama, Hamka in Howell, who introduces modern Sufism expresses that the important aspect to appreciate the essence of Sufism as self-development of ethics is to rebuild a religious devotion without affiliation of certain Sufi order, and yet people can regularly perform and practice it independently (2012: p. 61).

\section{Wahidiyah Interpretation on Su- fism}

In accordance with the development of Sufism in Indonesia, I want to reflect that shalawat wahidiyah performance has emerged another interpretation on how the teachings of Sufism is elaborated. According to Riyadi (2014: p.102), in his perspective of anthropology of Sufism, he asserts that Sufism should be dynamic in order to be a strategy for having dialog with modernity scientifically.

Sufism should openly receive the critics, it means that even though there have some debates about how to understand and actualize Sufism, the Sufism concept of strict understanding through religious narratives in the sense of Islam, have been diverse because of its historical proliferation. Hence, we could take some important book within the literatures of Sufism to counter various perspectives among scholars, such as, al-Risalah al-Qusyayriyyah, Kashf al-Mahjub, Ihya' 'Ulum al-Din, al-Hikam, etc (Ibid, 102-103)

In this perspective, I claim that we could not deny the various representations of Sufism among scholars, or practitioner of Sufism in the broader context in order to see how the multiple activities of Sufism are served. In Indonesian context, the closest aspect of Sufism is generally linked with group of Sufi order and its proliferation. Howell asserts, "Neo-Sufism is generally reserved for Sufism cultivated outside a Sufi order" (Ibid, p. 3). Following this idea, she wants to express that the Sufism could be performed by people without demanding to affiliate with Sufi order (tarekat) in accordance with 
Contemporary Sufism in the Muslim world.

In the diverse interpretation and representation of Sufism among Muslim(s), I will connect it with the issue of Wahidiyah teachings, where it is based on al-Hikam of Ibn Atha'illah al-Iskandari as the main references of how shalawat wahidiyah was created by the author, Kyai Madjid. Thus, to some extent I want convey that mostly the emergence of Wahidiyah teachings cannot be separated from the aspect of Sufism, yet it does not mean that the interpretation of Sufism within this group could be accepted by other Sufi groups. In fact, the critics also colors the historical background of shalawat wahidiyah, whether it is more closed to the concept of monism or dualism. Here, I want to assert that the aspect of Sufism of shalawat wahidiyah representation is in the middle position of both concept.

The performance of Sufism in Wahidiyah teachings do not use the term of monism and dualism, yet, it is based on the purpose of ma'rifat billah. An author of shalawat wahidiyah teaches the concept of Wahidiyah ula-ahadiyah and Wahidiyah tsani to the practice of shalawat wahidiyah performance. In the level of Wahidiyah tsani, it refers to the aspect of syariah including aqidah and various activities of syariah, where people could be aware of the existence of Wahidiyah, as spiritual path. Because people have to provide the interconnected substance (duniawiakhirat). Meanwhile, when it is in the stage of Wahidiyah ula-ahadiyah, the attendance of shariah blurred since people have attained to the highest stage as if human unite with God.

Following this perception, I assume that Wahidiyah ula-ahadiyah has closed representation with the idea of monism, and Wahidiyah tsani is more closed to the concept of dualism. In perspective of Sufism in broader context, the dualism means that there have two substances within human body, such as, soul and body; the soul lives in human body and body could be functioned because of the soul itself (Riyadi, 2014: p. 108). Meanwhile, according to Peter Salim in Riyadi, monism is a theory which claims that there has only one substance as the basic reality; it is divided into materialistic monism (This perspective implies that soul and body is one substance creating human personality) and spiritual monism; in Sufi itself, the second category is more often to be used as representation of Sufism teaching (Ibid: p. 121-122).

In line with both There has specific explanation from one of senior preacher in Wahidiyah responding to the presence of non-Muslim followers in Bali, $\mathrm{He}$ asserts,

In Wahidiyah Foundation, the term shari'ah is generally applied for the Muslim followers. Yet, shari'ah within Wahidiyah means that shalawat wahidiyah and all Wahidiyah teachings 
which are used to become the guidance for reciting SW, not shari'ah in Islam. When shari'ah is applied by Muslim, it means they are forbidden to leave and disobey shari'ah Islam as part of religious responsibility (refers to obligated worship). Meanwhile, the Hindu Balinese has its own limitation based on their own religion in which Wahidiyah will not make the boundaries for them. Wahidiyah is very attentive to what the rules are. The important thing is the followers of Wahidiyah should follow and provide Wahidiyah teachings and SW performance, particularly for expressing fafirru ilalloh (returning to God). Although Wahidiyah cannot be separated from Islam, yet the formula of Wahidiyah teaching is its difference. Further, shalawat wahidiyah can be recited everywhere including worship places associating with situation and condition, and "doa bersama" can be possibly held in temples.

In accordance with these ideas, I want to figure out that Sufism can be flexible and interchangeable based on the perspective used by practitioner of Sufism itself. In the context of Hindu Balinese, the teachings of Wahidiyah has been applied in multiple activities without deleting the main message of Sufism based on Wahidiyah approach of Ibn Atha'illah al-Iskandari. Among the basic references of Sufism, Al-Hikam is particularly one significant reference because it has universal value. Thus, the more diverse the interpretation of
Sufism, the more valuable the evolution of Sufism emerge among the society, particularly in Indonesian context. Even though Hindu Balinese do not become aware that what they did is part of Sufi practice, the Wahidiyah Foundation concerning on symbol of Sufism, attempts to accommodate the nature of Sufism in context of Balinese.

Ritual can be a strategic way to 'traditionalize', that is, to construct a type of tradition, but in doing so it can also challenge and renegotiate the very basis of tradition to the point of upending much of what had been seen as fixed previously or by other groups (Bell, 1992: p.124)

By quoting its statement, I consider that it links with the ritual in Wahidiyah under the agenda of mujahadah and "doa bersama" modified by a Hindu Balinese community of Wahidiyah follower through the practice of shalawat wahidiyah, as part of their spiritual path. In addition, it is also being the process of negotiation with the Wahidiyah Foundation in terms of possibility for Hindu followers to practice shalawat wahidiyah in line with Hindu Balinese's ways.

\section{Hindu's Adaptation to the Practice of Shalawat Wahidiyah}

According to Edward Shils, he argues logically, "beliefs could exist without rituals; rituals, however, could not exist without beliefs" (Bell, 1992: p.19). Following this idea, it closely 
links with the way how a Hindu Balinese community of Wahidiyah follower perform ritual in accordance with their identity, as Hindu Balinese. Thus, it could not be denied if the presence of individual subjectivity appears in terms of 'action' and 'though' of groups of people as what Bell says in the book of Ritual Theory, Ritual Practice. In line with the agenda of "doa bersama" in temples concerning on performing shalawat wahidiyah, a group of Hindu followers of Wahidiyah attempt to have some negotiations to adapt with process of "doa bersama" based on their Balinese ways. Firstly, Hindu Balinese can perform shalawat wahidiyah in the temples; they can wear customary dress while holding " $d o a$ bersama" in all agenda of mujahadah and "doa bersama"; thirdly, they start opening the agenda "doa bersama" by giving the offerings to Ida Batharal Bathara Guru (refers to the deva) and flaming incense; Hindu Balinese initiates the agenda of 'Safari Bulan Purnama' where the intersection of Hindu Muslim occur there; Hindu Balinese also ask Muslim followers to wear custom dress while entering temples to perform mujahadah and "doa bersama" in accordance with the rules of temples.

In regard to the ways how Hindu Balinese adapt with shalawat wahidiyah performance, Ida Rsi Bhujangga Waisnawa Dwija Hari Murti (an appellation of the highest level of religious spiritual teacher in Balinese society), asserts that all people can walk together by one vehicle to approach God if they have able to separate the terms and dominated words of religious languages. It is because Hindu Balinese generally understands that God creates atman in all His creation. In the other word, atman is a significant aspect within human beings.

You have to elevate your relationship between you, yourself and God, only through that way you will get in touch and be closed to God. Having the holiness of heart is more important than understanding the holy book (Veda). It is the key to understand what spirituality is. One factor is based on the power of mantram they perform and feel. Different people have different feeling to recite it. No one knows the quality of self-purification to find the Truth, yet only He himself, she herself. Because guru sejati is within our own heart, not in another place. In the end, the real Self will be broken. What exists is Atma and atman is the little particle of Brahman. "sesungguhnya kita berasal dari sesuatu yang sama" and Brahman is everywhere. It is why Hindu Balinese is different from other religions.

What can be highlighted from this context is on the Hindu Balinese perspective in activity of reciting shalawat wahidiyah as mantram suci in accordance with their association of communal practice at "doa bersama". In other word, mantram could bring 
Hindu Balinese to the higher level of self-purification to approach God if they are able to raise the spirits of its mantram . Titib asserts that mantram could be functioned as a tool for influencing the connection of mind and act in the way how to control negative effect of displeasure feeling to other people (2003: p. 465).

Following the statement above, we can also look at religious interpretation of people from different religion in the way how people try to perform their belief.

Religious beliefs have been understood in a variety of ways - as pseudoscientific explanations, rationalizations of customary behavior, personal or communal ideologies, or highly structured doctrinal formulations whose content has little import on behavior (Bell, 1992: p.182)

I consider that Bell's view links with Hindu followers of Wahidiyah who have the ability to transform their belief through "doa bersama" in the ritual activity at the temples when the dates of purnama. Whereas the use of custom dress symbolizes the local sign to express their religious identity as Hindu Balinese. Upon Balinese ritual, it becomes the basic consideration on the religious performance and culturespecific interpretation of providing worship in the temples. I reflect that it refers to the normative aspects to represent Provincial Government Regulation of Bali Number 16 Year
2009 about Geographical Planning of Bali Province Year 2009 - 2029 (Peraturan Daerah Provinsi Bali Nomor 16 Tahun 2009 About Rencana Tata Ruang Wilayah Provinsi Bali Tahun 2009 - 2029 / RTRWP).

"today, the national laws and provincial regulations allow a conflation of what were earlier seen as separate domains. In other provinces of Indonesia, such as West Sumatra, the abolition of desa dinas and a return to the 'traditional' political structures based on adat has already taken place" (Hauser-Schaublin, 2011: p. 200).

In this position, the protection of holy areas of temples are included in its RTRWP in accordance with religious aspects of Hindu tenets. Besides, the local wisdom (kearifan lokal) in Bali is also arranged there. Supported by Bhisama from PHDI (Parisada Hindu Dharma Indonesia), it appears that a legalization of RTRWP is a form of privilege had by Balinese society as the largest population for Hindu in Indonesia.

In accordance with the notion of ritual practice, basically Bell uses the term 'ritualization' because it is a way of action drawing the attention to differentiate certain social actions with other actions culturally (Ibid, p.74). It means that the expression of acting ritually could emerge various strategies in order to categorize the distinction of ritual activities. In Bali itself, we could see that Hindu followers of Wahidiyah have authority to explore all activities related to $z i k r$ ritual in their local 
ways, in which they try to modify the Islamic nuance of shalawat wahidiyah performance through Hindu Balinese ways.

Relating to the modification conducted by a group of Hindu Balinese followers of Wahidiyah, the tension occurs among the Muslims follower of Wahidiyah in Bali. Firstly, it comes from a group of Muslim who involve in the beginning event of mujahadah and "doa bersama" in temples with a group of Hindu followers. The Muslim(s) agree with the idea offered by Hindu follower because those Muslim(s) realize that some Hindu followers feel insulted when Muslim followers spread and communicate about the Wahidiyah Foundation and its practices using religious language associated with Islam, and they have no space to Hindu Balinese to utilize their own religious language. Besides, they want to apply the guidance of Wahidiyah Foundation in Kediri that the Wahidiyah followers have to provide the three significant principles to the practice of shalawat wahidiyah. Thus, the flexibility of applying the shalawat wahidiyah is conducted in accordance with the basic references and guidance from the highest authority in the Wahidiyah Foundation. Nevertheless, the Muslim tension comes from a group of Muslim officials of Wahidiyah follower in Bali. They give some assertions that all Wahidiyah followers in Bali province have to follow the rules created by Wahidiyah Foundation in Kediri, including the agenda(s) of mujahadah, the quantity (aurod) that should be recited, and the places to hold mujahadah itself. A Muslim representative of the officials in Bali states, "As Muslim, it is clear that we are forbidden to hold a form of prayer $(d o a)$ in other religious worship places. Thus, every Muslim(s) followers of Wahidiyah in Bali should be careful of this issue". In this sense, it seems that the Muslim officials of Wahidiyah in Bali apply the rules of Wahidiyah rigidly since they also use their personal understanding which may be different from what the Wahidiyah Foundation in Kediri has.

In my opinion, regardless people are from the Wahidiyah followers or not, it links to Indonesia context where the worry of violating religious identity will emerge if people do contact with different religions by entering the worship places and do prayer inside. Firstly, it may be caused by the weakness of social relation among religious diversity. Secondly, it may be influenced by self-representation of religion which could come from text interpretation literally, meaning that there has an absence of context when religious ritual is applied.

Responding to this issue, I want to highlight that it is significant to divide Islam as religion and Muslim as an offender in a religious community (Wahidiyah Foundation). 
Since individual understanding of certain aspect in line with religious interpretation could not be used as standardization of applying Islam itself. Despite the references coming from religious texts, we have to be attentive to what people stated in line with their understandings. Moreover, not all Muslim(s) affiliate with religious communities to express the religiosity toward ritual.

Exploiting religious symbols could emerge the contra-productive attitude and in certain level it can build people' $\mathrm{s}$ fear to what they have seen. Now, we have to support the substantial process in understanding religion itself. In the way how to actualize religion, primer need is not simply provided by symbol and identity, rather it is closely related to an aspect of substance, namely consciousness and behaviour (Mas'udi, 2003, p. 135).

Following this perspective, Mas'udi adds the utterance (sabda) of Prophet Muhammad: laa yandzuru ilaa shuwasatikum wa la ilaa ajsamikum wa la ila a'malikum wa lakin yandzuru ila qulubikum means that "Alloh will not see the form of outer deed (lahiriyah), even charity, yet what is noticed is heart". Thus, to some extent the presence of Wahidiyah Foundation in Bali, as one of religious spiritual group in Islam, should not dominate Hindu Balinese in the way how they perform their own religion throughout the practice of shalawat wahidiyah. Picard
(2011) demonstrates;

"grateful to the Balinese for having preserved Hindu texts and rituals from the depredations of Islam..... Accordingly, it had to be protected, through the enlightened paternalism of colonial tutelage, from the intrusion of Islam, which had strengthened its grip on the better part of the Archipelago, as well as from Christian missionaries, eager to set foot on the island" (p.119)

In accordance with the issue above, each follower of Wahidiyah has the responsibility to spread the practice of shalawat wahidiyah to all people, including non-Muslims, as part of da'wah without the intention of it being a conversion mission. This is related to the three principles applied by the people who spread shalawat wahidiyah (penyiar shalawat wahidiyah), namely: adhering to the state ideology (Pancasila, UUD, and NKRI); respecting the local rules of the place including culture, tradition, customs; and maintaining religious beliefs.

In accordance with paragraph above, I argue that these three principles are important to avoiding the suspicion towards the religious community of Islam introducing others to the shalawat practice, particularly in context of Balinese society where the majority of inhabitants are Hindu. Shihab states that "in the sense of 'ethic of sharing' people have to build self-consciousness within themselves in which it emphasizes on the understanding that many paths of approaching God exist, otherwise 'each chosen not only for a mission but for special affection (2014: p. 
188). Following Shihab, I want to reflect that the three principles above are linked to an ethic of how people spreading shalawat wahidiyah do not merely become emissaries of the mission of $d a$ 'wah. Particularly for Hindu Balinese, they then do not worry of losing their faith while performing $z i k r$ ritual of other religious beliefs because of the three principles above. In that sense, it does not mean that the three principles are only applied in Balinese society, but in all areas. Those are a form of approach used by the Wahidiyah Foundation to spread and share shalawat wahidiyah for nonWahidiyah (referring to non-followers of Wahidiyah). Otherwise, it is one factor why the followers of Wahidiyah are diverse in Bali.

Following this issue, I reflect that it is a form of evolution that have made by Wahidiyah Foundation in Kediri, as the contact with non-Muslim group, this is significant because Wahidiyah Foundation attempt to adapt with Indonesia context where there has a lot of tension and concern about the worry which does not overstep people's religious boundaries in the way how people practice universal perspective of teachings itself. Although what Wahidiyah Foundation did is such as universal spiritual path, people have to be careful since it is sensitive aspect around this issue surrounding diverse societies of Archipelago.

\section{Conclusion}

To sum up this research, I want to assert that shalawat wahidiyah is a particular case under the Wahidiyah Foundation which could represents a 'grup tasawuf' of Indonesia that promotes the formula of prayer in line with religious diversity through a spiritual path, namely mujahadah and "doa bersama". In this sense, I convey that Sufism teaching does not tend to be represented only by groups of Muslims, yet it could encounter nonMuslim community as one inspiration of spiritual path to transform their own interpretation of God's existence.

Today, the proliferation of religious organizations in Islam tends to restrict the flexibility of religious interpretations, since people try to focus on normative textual understandings of how the ritual should be performed. The presence of religion is more often used as a tool to create strong boundaries between believers of different religions. Thus, to some extent, inviting other religious groups to participate in a ritual practice seen as a symbol of religious identity is easily misunderstood or suspected to be a covert method of proselytization. In this sense, it is linked to the tension among Wahidiyah followers in Balinese society. Some Muslim Wahidiyah followers think that the shalawat wahidiyah ritual must be done according to strict textual interpretations, while others Muslim Wahidiyah followers are more 
open to allowing non-Muslims to adapt the ritual practice to their own interpretations.

Following that debates, the involvement of a Hindu Balinese community in the Wahidiyah Foundation, an Islamic organization in Indonesia, demonstrates how nonMuslim practice of zikr may result in two different responses. Firstly, it is a way to build religious inclusiveness by utilizing an interpretation of zikr as a universal ritual practice that anyone of any religion can participate in. However, when the practice of $z i k r$ ritual is done by non-Muslims, it can cause the emergence of religious tensions because $z i k r$ is identified as a Muslim practice in Indonesia. In addition, the religion is a source of identity that serves to maintain the boundaries between people, reflected in the way people express their religious identity. By observing a Hindu Balinese community of Wahidiyah followers, I argue in that it is the Sufistic interpretation from the Wahidiyah Foundation about the meaning of shalawat wahidiyah that allows nonMuslim followers to adapt the practice of zikr in line with their own religious interpretations about returning to God.

In that sense, we can learn from this issue is the ability of a minority group to be flexible towards other interpretations of the religious ritual as long as it does not violate both the religious identity and the certain culture in line with the condition in the society, particularly in the diverse societies of Indonesia. Thus, the prejudice of proselytization does not appear since the presence of religious boundaries could be applied by Hindu Balinese follower of Wahidiyah in line with a universalistic kind of practicing the shalawat wahidiyah and the interpretation of their religious belief. Additionally, in the Indonesian context, all people have to maintain the boundaries of religious identity when they are involved in ritual practices identified with other religions.[]

\section{References}

An-Naisaburi, Abul Qasim Abdul Karim Hawazin. (2007). Risalah Qusyairiyah: Sumber Kajian Ilmu Tasawuf. Jakarta: Pustaka Amani.

Bell, Catherine. (1992). Ritual Theory, Ritual Practice. Oxford: Oxford University Press.

Creswell, John. W. (2007). Qualitative Inquiry \& Research Design: Choosing Among Five Approaches. Second Edition. Sage Publication, Inc.

Hauser-Schäublin, B. (2011). Spiritualised Politics and the Trademark of Culture. The Politics of Religion in Indonesia: Syncretism, Orthodoxy, and Religious Contention in Java and Bali, 167-191.

Hornbacher, Annette. (2011). The Withdrawal of the Gods: Remarks on Ritual Trance- 
Possession and Its Decline in Bali. In the Politics of Religion in Indonesia: Syncretism, Orthodoxy, and Religious Contention in Java and Bali. Edited by Michel Pichard and Remy Madiner. NY: Routledge. p. 167 - 191.

Howell, J. (2012). "Introduction: Sufism and neo-Sufism in Indonesia Today". Review of Indonesian and Malaysian Affairs. Vol 46, No. 2, p. 1 - 24.

Huda, Sokhi. (2008). Tasawuf Kultural: Fenomena Shalawat Wahidiyah. Yogyakarta: LKiS.

Mas’udi, Masdar Farid. (2003). Agama dalam Konflik Sosial. In Islam Pribumi: Mendialogkan Agama, Membaca Realitas. Edited by Sayed Mahdi \& Singgih Agung. Jakarta: Erlangga. p. 133 - 143.

Mulia, Musdah, ed. (2000). Pedoman Dakwah Muballighat: Menuju Masyarakat Madani. Jakarta: DPP Korps Wanita MDI.

Pichard, Michel. (2011). "From Agama Hindu Bali to Agama Hindu and back: Toward a relocalization of the Balinese religion?". In the Politics of Religion in Indonesia: Syncretism, Orthodoxy, and Religious Contention in Java and Bali. Edited by Michel Pichard and Remy Madiner. NY: Routledge. p 117 - 141.

Riyadi, Abdul Kadir. (2014). Antropologi Tasawuf: Wacana Manusia Spiritual dan Pengetahuan. Jakarta: LP3ES.

Simuh. (2016). Sufisme Jawa: Transformasi Tasawuf Islam ke Mistik Jawa. Yogyakarta: PT. Buku Seru.

Swidler, Leonard. (2014). Dialogues for Interreligious Understanding: Strategies for the Transformation of Culture-Shaping Institutions. New York: Palgrave Macmillan.

Titib, I Made. (2003). Teologi dan Simbol-Simbol Dalam Agama Hindu. Surabaya: Paramita.

Zamhari, A. (2008). "The development of chanting groups in East Java: A case study of the Salawat Wahidiyyah group in Pesantren Kedunglo, Kediri”. RIMA: Review of Indonesian and Malaysian Affairs, 42(1), p 125-156. 